\title{
THE USE OF BIG DATA IN HEALTHCARE: LESSONS FOR DEVELOPING COUNTRIES FROM UZBEKISTAN
}

\section{ZASTOSOWANIE BIG DATA W OCHRONIE ZDROWIA: INFORMACJE DLA KRAJÓW ROZWIJAJĄCYCH SIĘ NA PRZYKŁADZIE UZBEKISTANU}

\author{
Igor Vikhrov $^{1(\mathrm{~A}, \mathrm{C}, \mathrm{E}, \mathrm{F})}$, Zokhid Abdurakhimov $^{1(\mathrm{D}, \mathrm{G})}$, Sherzod Ashirbaev $^{1(\mathrm{~B})}$ \\ ${ }^{1}$ Innovation Centre, Tashkent Pediatric Medical Institute, Uzbekistan
}

Authors' contribution Wkład autorów: A. Study design/planning zaplanowanie badań B. Data collection/entry zebranie danych C. Data analysis/statistics dane - analiza i statystyki D. Data interpretation interpretacja danych E. Preparation of manuscript przygotowanie artykułu F. Literature analysis/search wyszukiwanie i analiza literatury G. Funds collection zebranie funduszy

Tables: 0

Figures: 3

References: 35

Submitted: 2021 March 27

Accepted: 2021 May 14

\section{Summary}

The use of Big Data (BD) in medicine is fundamental for the development of digital healthcare, including the implementation of smart medicine and artificial intelligence (AI) technologies. Proper organization of BD is necessary for the creation and training of AI algorithms, and for AI to work with great efficiency and accuracy. In this review, the existing models for creating and storing BD sets are described, and the numerous opportunities provided to the healthcare system by the effective use of these tools are outlined. The BD phenomenon is especially important for the developing countries, which can use the example of already completed projects and achievements in the field of BD to more effectively implement such technologies in their own countries. However, there are still some problems with the implementation of BD technologies in practical healthcare of the developing countries. One of the fundamental issues is the financial cost of developing, implementing and maintaining a system for collecting, storing and using BD, including the cost of highly qualified personnel, and expensive equipment and network infrastructure that needs to be regularly updated. Another problem is the confidentiality and security of data in healthcare.

Keywords: Big Data, artificial intelligence, healthcare, medicine, digitalization

\section{Streszczenie}

Zastosowanie Big Data (BD) w medycynie jest kluczowe dla rozwoju cyfrowej opieki zdrowotnej, $\mathrm{w}$ tym technologii smart $\mathrm{w}$ medycynie i wprowadzeniu technologii sztucznej inteligencji (AI, ang. artificial intelligence). Bez dobrze zorganizowanej technologii BD nie ma możliwości stworzenia i dopracowania algorytmów AI. Tylko wtedy AI będzie mogło pracować skutecznie i dokładnie. W niniejszym przeglądzie, autorzy analizuja istniejace modele tworzenia zestawów BD, przechowywania ich, a także wiele możliwości, które otwierają się dla systemu opieki zdrowotnej w przypadku skutecznego zastosowania BD i AI. Zastosowanie BD jest szczególnie istotne w przypadku krajów rozwijających się, które mogą korzystać z przykładów zrealizowanych projektów i osiągnięć w dziedzinie BD, w celu wdrożenia takich technologii w swoich krajach. Niemniej jednak, w praktyce, wdrożenie technologii BD w służbie zdrowia rozwijających się krajów wiąże się z różnymi problemami. Jedną z najbardziej istotnych kwestii jest koszt rozwijania, wdrażania i utrzymania systemu zbierania, przechowywania i wykorzystywania BD, włączając $w$ to wysoko wykwalifikowany personel oraz kosztowne wyposażenie i infrastrukturę sieci, która musi być regularnie modernizowana. Kolejny problem stanowi natomiast kwestia poufności i ochrony danych w służbie zdrowia.

Słowa kluczowe: Big Data, sztuczna inteligencja, opieka zdrowotna, medycyna, digitalizacja 


\section{Introduction}

The implementation of digital technologies is one of the top priorities for developing the healthcare sector worldwide, and the market for these technologies is growing by a quarter every year. Digital technologies can provide breakthroughs in the availability and quality of healthcare services without increasing costs. Therefore, the development of digital medicine is carried out with the active participation of the state. Over the last two decades, a sequential process has emerged to deal with the problems of informatization and digitalization in the healthcare system. This approach starts with the development of information and communication infrastructure (i.e., Information Technologies [IT] infrastructure), which includes the expansion of network infrastructure, access to broadband Internet, and universal computerization of workplaces. This is followed by the development of e-health, and after collecting, storing and analyzing the necessary patient data in electronic form, the emergence of so-called data technology or big data (BD). This latter process is dependent upon the powerful thinking capabilities of modern processors and the ability to purchase the necessary equipment. BD collection is typically followed by the implementation of Artificial Intelligence (AI) and the Internet of Things (IoT) technologies, which can participate in the processing of information, the development conclusions, and can predict the results of processes without human participation.

While the speed of IT development in the Republic of Uzbekistan can be considered satisfactory, the development of BD, AI and the IoT causes some concern. Within the healthcare system, the issues of informatization have been actively addressed, as broadband access to the Internet is organized and the minimum network infrastructure has been provided to almost all healthcare facilities. In Uzbekistan, a corporate network of the Ministry of Health has been created, many information systems have been developed and implemented, and, all health facilities are provided with computerized work stations.

However, in our opinion, there are several difficulties with developing BD, data science and AI technologies in Uzbekistan. First, there is a lack of uniform national standards for electronic patient records and the electronic storage of diagnostic data, such as X-rays, magnetic resonance imaging (MRI), and pathological examination data. In addition, there has been an absence of public discussion on protection of the personal data of patients, moral and ethical guidelines for the use of AI technologies and, accordingly, imperfections in the legislation in this area. Furthermore, there is a general lack of specialists and professionals working in the field of healthcare digitalization. These issues limit the ability of local scientists to carry out scientific research in this area and hinder the practical implementation of BD and AI technologies in healthcare in this region.

\section{Aim of the work}

The main purpose of this review is to examine the use of BD in healthcare and to outline regulatory issues with the use of databases in various countries. We also provide recommendations for decision-makers involved in the implementation of digital healthcare in developing countries like the Republic of Uzbekistan.

\section{Methods}

A literature search was carried out to find articles about the use of BD in healthcare. The following search terms were used: "big data in health" and "big data in medicine". These terms were used with PubMed, Springer Nature, and Google Scholar to find both peer-reviewed publications and professional journal articles addressing an exploitation of BD in the health domain. The primary search only included articles published between 2016 and 2021. However, a secondary search was carried out to identify articles published before this timeframe that could be used to form a discussion of the problems revealed in recent articles.

\section{BD terminology and its attributes}

English dictionaries and glossaries generally define the term "Big Data" in a similar fashion, and several examples of these definitions are outlined below. The Cambridge English Dictionary defines BD as massive data sets that are produced by people using the Internet, and which can be stored, understood and used only with the help of special tools and methods [1]. The Collins English Dictionary defines BD as extremely large amounts of information that can only be used with the help of special computers [2]. Longman's Dictionary of Modern English treats BD as enormous amounts of information that can now be collected, stored, and analyzed, especially information about people's interests or what they like, for example, because of things like the use of social networks [3]. 
In the Russian-language literature and the Internet (Runet), widespread use of the term BD is attributed to a former editor of Nature, Lynch, who in his publication translated from English into Russian "Big Data: How does your data grow?" discussed explosive growth in the volume of information [4]. However, Kornev, in his work, suggested that the term "Big Data" was used by scientists and researchers earlier in the 20th century, indicating a rather long history for this term [5]. Similar to Kornev, we could not find the term "Big Data" in Russian-language dictionaries at the time of this writing.

Generally, the term "Big Data", in almost all works, is characterized by the presence of a huge array or volume of information that is processed and analyzed by powerful computer processors with the support of algorithms and AI technologies like machine and deep learning. Despite the widespread use of BD, namely in information and communication technologies, an exact definition of this term does not yet exist.

In the literature, there is also outlined a certain relationship between BD and AI. A scientific publication on AI and its formulation, presented by Kaplan and Haenlein, describes AI as "a system's ability to interpret external data correctly, to learn from such data, and to use those learnings to achieve specific goals and tasks through flexible adaptation" [6]. There are two popular definitions of the term AI:

1. the property of intelligent systems to perform creative functions, which are traditionally considered the prerogative of mankind [7];

2. the science and technology of creating intelligent machines, especially intelligent computer programs, where $\mathrm{AI}$ is associated with the similar task of using computers to understand human intelligence, but is not necessarily limited to biologically plausible methods [8].

Data is the "fuel" for AI. The more data the algorithm processes, the more accurately and correctly it will be able to formulate conclusions based on them. Medicine is a field with a large amount of data, where accuracy is perhaps the most critical factor.

To summarize this section, we would like to emphasize that AI is both a science and a practice, with science helping to create "smart" machines, and practice helping machines to learn and make decisions through machine learning. Machine learning is based on algorithms that analyze data, including BD, and draw conclusions and make decisions based upon them. These conclusions and decisions can be made with the help of deep learning, which is just one of the methods of machine learning where a computer learns, without a teacher on its own, using BD.

The growing popularity in BD can be demonstrated by examining the changing dynamics in Internet searches for this term. Here, we used Google Trends to examine this. This tool allows users to track the history of web search queries over time [9]. The results of this analysis are shown in Figure 1. The Y-axis indicates the average use of a particular search term over a certain period of time for a given region. The numbers represent the ratio of the number of requests for a particular word or phrase to the total number of requests. The data is normalized (i.e., translated into a 100-point scale), where the largest relative indicator is assigned 100 points, and the remaining values are compared with it and assigned a number from 0 to 99 . A value of 100 represents the peak popularity for a search term, a value of 50 means that the term is half as popular, and a score of 0 means there was not enough data for this term. As can be seen in Figure 1, the strong growth of interest in BD began in 2012 and continues to the present. It can also been seen that web searches for "BD in health" remain relatively low. However, this should not detract from its importance for theoretical and practical medicine. 


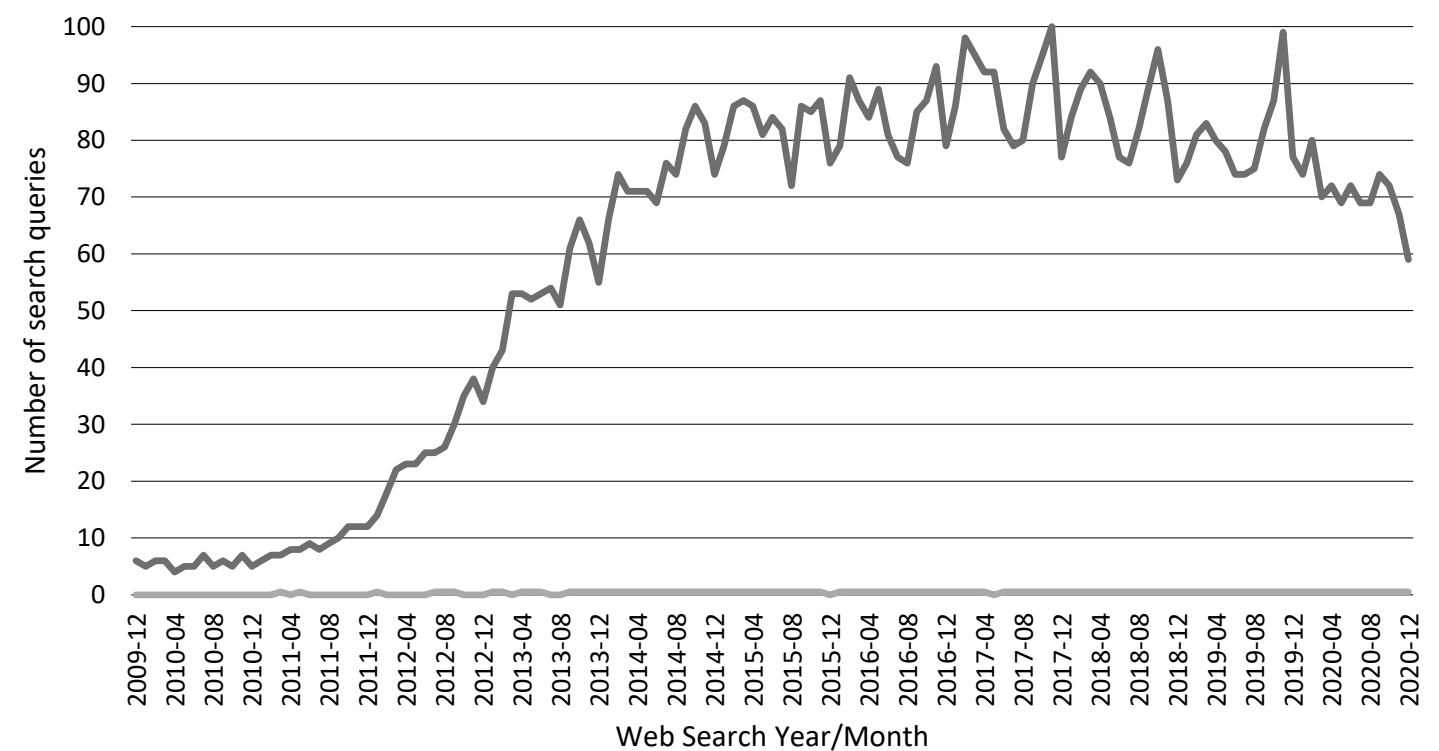

Big Data $\quad$ Big Data in Health

Figure 1. Comparative analysis of the trend in web search queries for the terms "BD" and "BD in Health" for the period $2009-2020$

Indeed, the total number of scientific publications in the field of BD in the Springer nature database was 661,292 for the period of 2009-2020. For BD in health, the number of publications for the same period was 219,850, which is about three times less [10]. These data are shown in Figure 2.

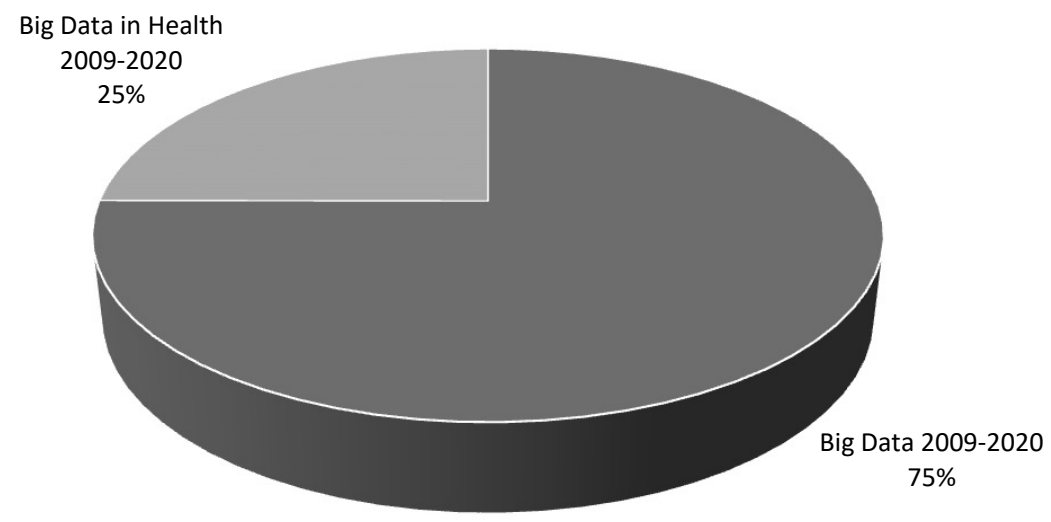

- Big Data 2009-2020 — Big Data in Health 2009-2020

Figure 2. Comparative analysis of the scientific queries results in the Springer Nature database for the terms "BD" and "BD in Health" for the period 2009-2020

Laney in his report on the problems of centralized data storage, proposed the so-called $3 \mathrm{~V}$ (volume, velocity, variety) approach to defining and conceptualizing methods for database management, then still outside the context of $\mathrm{BD}$ [11]. The $3 \mathrm{~V}$ approach was later applied to $\mathrm{BD}$ and underwent an upgrade, increasing from $3 \mathrm{~V}$ to $7 \mathrm{~V}$. The 7 "V" attributes and their application to BD are outlined below:

1. Volume. BD is characterized by a large amount of information (e.g., terabytes and petabytes of information);

2. Velocity. BD is constantly updated and, accordingly, constantly processed, which implies an increase in volume;

3. Variety. The data can be different (i.e., structural, nonstructural, or only partially structured); 
4. Veracity. The data must be verified and reliable as the results of an analysis and any conclusions are dependent upon the quality of the initial data [12];

5. Variability. This feature is characterized by components such as the context in which BD are collected and analyzed;

6. Visualization. The analysis of BD is impossible for the human brain, especially with regard to visual perception and drawing conclusions. However, with the help of BD visualization, an individual can understand, draw conclusions, and make decisions based on BD [13];

7. Value. This refers to getting the most out of the results of BD analysis. For example, how the insights gained from data analysis can be used to make informed decisions [14].

BD may not always correspond to all $7 \mathrm{~V}$ attributes, but we believe that it is crucial for all scientists and practitioners working in the fields of BD and AI to strive to develop and implement all of the above features. They do not necessarily have to be in the order presented, and the data may not always provide value in the near future or in a short period. Based on the attributes of BD, scientists and practitioners can get a more reliable analysis, and thus make better decisions based on the evidence.

\section{The role of $\mathrm{BD}$ in healthcare}

Today, medicine and healthcare generate a huge amount of information, and the production is increasing at a rapid pace. According to IBM Research (the Research and Development Department for IBM, a multinational information technology company from the United States and the world's largest research organization in the field of industry), an ordinary person produces about 1 petabyte (1 million gigabytes) of medical data in his or her life. The Stanford University School of Medicine also noted in its analytical report in 2013 that about 153 exabytes of information ( 1 exabyte $=1$ billion gigabytes) are produced annually, and, according to forecasts, 2,134 exabytes data will be produced in 2020 (i.e., an increase of 48\% per year) [15]. Densen also reported that the volume of medical data doubles every three years. However, in 2011 and in 2020, according to the author's forecast, it began to double every 73 days [16]. The Data Attack Surface Report (2020) predicts that the amount of data in the cloud will reach 100 zettabytes by 2025 - about $50 \%$ of all digital data in the world [17]. Moreover, $80 \%$ of all new data will be generated not by humans, but by smart gadgets. Most of the data are produced in four economic areas: industry, the financial sector, the media business and healthcare. Due to the COVID-19 pandemic, data output from healthcare has likely decreased but, even before 2020, there was a huge amount of data produced by this industry. Healthcare data includes patient information, such as medical histories and treatment regimens, as well as information on the workload of hospitals, their equipment, the number of staff, etc.

It has been estimated that up to $30 \%$ of all data stored in the world is related to health [18], and that one individual patient can generate up to 80 megabytes of imaging and Electronic Medical Records data per year on average [19]. The largest data sources are X-ray and MRI images, and omics data, such as complete genome sequence data [20]. The IoT, medical devices with WiFi modules, laboratory results and self-diagnosis results, smartphones and health trackers can continuously provide data online. Taking into account the digitalization of all areas of life, there are already tens of thousands of data points per patient. At the same time, there is still a manual recording of the patient's condition, which is unstructured data, but its importance for the development of intelligent medicine systems is clearly high. Thus, without the use of modern IT equipment and BD analysis technologies, it is impossible to process such a flow of information. In this regard, the role and importance of BD in healthcare is growing even more.

White conducted a literature review examining the features of the use of BD in the United States. It should be noted that medical care in the United States is insurance-based, where citizens and employers purchase policies from insurance companies, which then provide opportunities to cover healthcare costs. The author concluded that the driver of changes and improvements in the quality of medical care is often insurance companies that are financially interested in lowering the financial costs of medical services. It was also noted that BD not only optimized financial spending on healthcare but also begin to act as a trigger for the use of information and communication technologies in medicine [21]. Suter-Crazzolara Clemens suggested that the effective use of BD in medicine is hindered by data privacy issues. Privacy concerns have led to a highly regulated industry, resulting in the digitalization of healthcare progressing more slowly than in other industries [22].

In their work, Dash et al. focused on the importance of healthcare professionals being fully equipped with the appropriate infrastructure to systematically generate and analyze BD to help make appropriate decisions to improve public health. The authors argue that effective management, analysis, and interpretation of BD can transform healthcare, opening up new opportunities for modern medicine. Moreover, the authors highlight the 
huge potential of BD in the integration of biomedical and medical data, where modern medical organizations can radically change medical therapy and institute personalized medicine [23].

BD are also used in areas of public health such as epidemiology, environmental health and occupational health, where data collected for other purposes can be applied to these areas of medicine. Stieb et al. reviewed the literature in this area and concluded that BD can inform occupational health by using innovations related to nontraditional sources of these data, as well as through new partnerships with other areas of the national economy [24]. Promising information systems include both real-time analysis and forecasting, as well as innovative analysis of clinical trial data or observations originally collected for other purposes.

A large number of studies have also been conducted on the impact and use of BD on the health economy [25-27]. Data from these studies suggest that routine and large-scale data collection on treatment costs and outcomes will allow economic health analysis to be applied to specific diseases and populations. However, such analyses may require the development of new skills. In this area of research, there are great opportunities for the collection of biomonitoring and population lifestyle data that can be used for economic health analysis and public health policy.

A separate line of research in the area of BD and health concerns the simulation of health events using BD. In this regard, the work of Johnson et al. is interesting, as it provided an analysis of the use of dynamic simulation models with electronic patient records. This research used secure links to the Leeds General Infirmary Information System with data from 3 million secondary and tertiary care patients. A dynamic modeling tool called NETIMIS (Network Tools for Intervention Modeling with Intelligent Simulation) was developed to visualize both human-developed and derived AI that could be used for what-if analysis by stakeholders to determine cost, and to develop and evaluate medical interventions [28]. An additional study on the use of dynamic simulation models of BD in healthcare has described the mutually beneficial synergy between BD and these models. The authors presented practical considerations and challenges, and outlined how the integration of BD and dynamic simulation models can be useful for decision-makers to address the complex, systemic issues of health economics and outcomes, and to improve the quality of healthcare [29].

Other research on the use of BD in healthcare has focused on the issue of a new paradigm known as patientcentered or personal medicine. These studies aimed to address whether BD can improve the quality of medical care for an individual patient, including improvements in prevention, diagnosis, and treatment. In this area, public health and epidemiology are now beginning to actively accumulate achievements in the fields of technology, BD, AI and the IoT $[30,31]$.

To summarize this section, we would like to note that there are still certain problems and difficulties that need to be addressed regarding the widespread implementation and use of BD in healthcare. While BD analysis has a huge potential to improve the quality of health services, there are still significant barriers to overcome before the potential can be fully realized. Data accuracy and completeness, linking disparate data sources, and data access are areas that require special attention. BD development strategies such as improving clinical coding, innovative mapping methodologies, and investments in BD standardization are potential solutions to the data validation and linking problems [32]. In 2016, the WHO Regional Office for Europe presented the results of a study of e-health systems in its region, which involved 46 countries, including Uzbekistan [33]. The frequency of use of standards for filling in, storing, and transmitting medical data, including images and videos, is shown in Figure 3. 


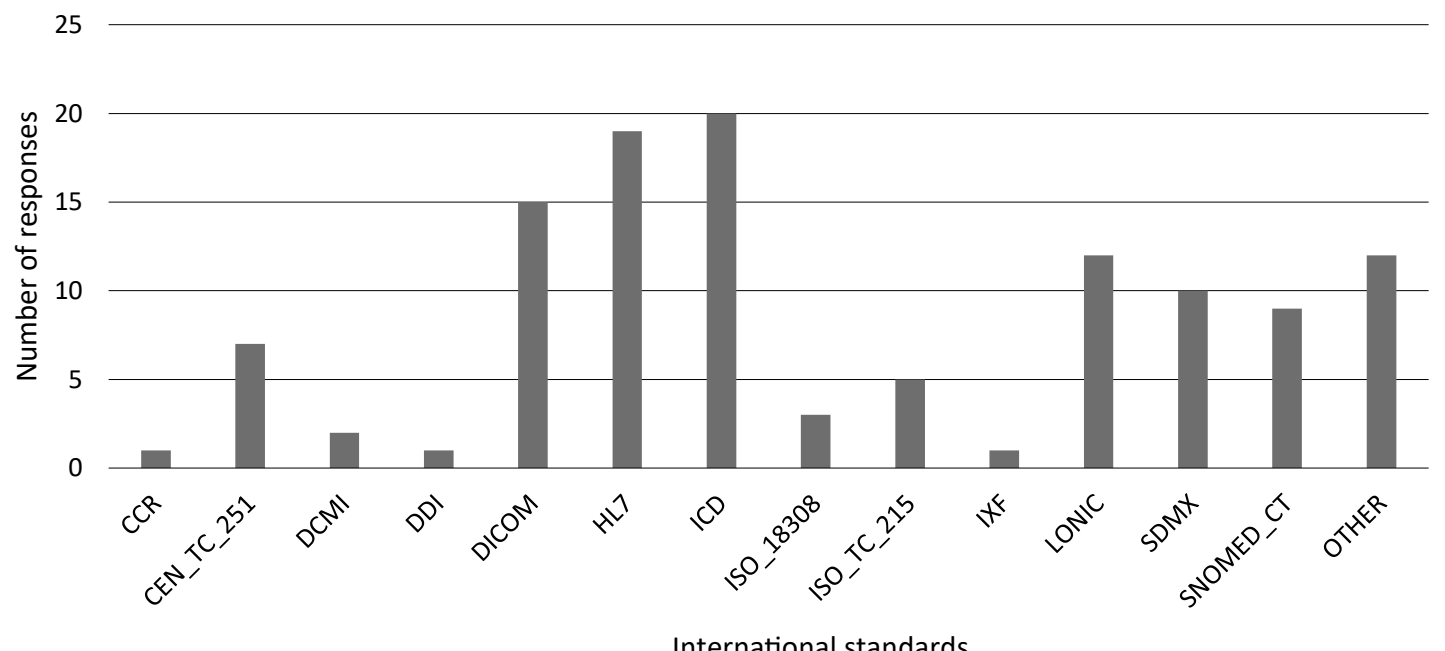

Figure 3. International standards used to support the national Electronic Health Records system

According to the results of the study, only 4 of the presented standards are used in Uzbekistan (CEN_TC_251, DICOM, HL7 and ICD), indicating a lag compared other countries. In general, standards such as SNOMED CT, DICOM, HL7 and ICD have become the most widespread for using and storing BD in medicine. Therefore, the use of these standards is the most optimal for Uzbekistan and for countries at a similar level of economic development.

Data access issues continue to require significant attention. Data ownership, security needs, and costs represent significant barriers to access and, consequently, to the development of AI technologies in healthcare and medicine.

\section{Regulatory and legal aspects of the use of BD in healthcare}

In the era of digitalization of all sectors of the national economy and services, when the borders between countries, economies, sectors of the national economy and even people are absent, the issues of personal data regulation are central not only in healthcare. Since ancient times, one of the principles of the Hippocratic oath was the confidentiality of patient data. This principle has now passed into the laws and norms regarding the provision of medical services in most countries. It is obvious that BD are made up from the so-called "small data" that form them. The decision to give permission for the processing of personal data is an immanent right of every person, and the withholding of data by individual patients presents an ethical dilemma and an analysis issue for BD processing. At present, there is no single approach for solving this dilemma among scientists, public and cultural figures, economists, sociologists, lawyers, and the medical community. Below, we cite several scientific papers that have offered their conclusions and findings after studying this topic.

Kolasa etal. explored the future of BD and data analytics in light of EU regulations on the protection and storage of personal data. Data collected from de-identified individuals across the healthcare continuum represents the most valuable source for BD in medicine. However, in the EU, assessing the value of the data has become a difficult task, as people have recently been granted the right to delete their personal data upon the withdrawal of consent, or when these data are no longer considered necessary. This law may limit the usefulness of BD in the future, as it may lead to misrepresentation. Among health system actors, this has become an important topic of discussion, as it relates to the importance of data, on the one hand, and the need to protect personal data on the other. The protection of health information is especially important when it comes to "personal data related to the physical or mental health of an individual, including the provision of medical services that disclose information about their health status." At the forefront of these discussions are issues of data protection, as well as public confidence in digital services. The authors concluded that a new era has begun when citizens and patients will be able to manage their personal or self-generated data [34].

Thus, the European experience in this area is based on a strict regulation of the protection of personal data. According to the European Commission, the unrealized growth potential of the EU digital economy due to the introduction of these regulations is 450 billion euros per year. By contrast, the American experience more supports market mechanisms for data turnover, which actively increases innovation and, accordingly, increases the competitiveness of the United States. According to experts, the United States is the market leader in BD 
processing and analytics. In the coming years, the US market will account for more than half of the investment in the global segment of BD technologies. In China, the experience is based on the introduction of the maximum national favorability regime. As a result, China allows businesses and, at the same time, the state to introduce innovative services and systems.

In Uzbekistan, the Presidential Decree of 17the February 2021 "On measures to create conditions for the accelerated introduction of AI technologies" was adopted. The decree approved a list of pilot projects for the introduction of AI technologies in various fields, which will be implemented in 2021-2022. Among them, the health system is expected to develop AI technologies for the diagnosis of pneumonia based on the analysis of computed tomography of human lungs, as well as breast cancer in the early stages based on the analysis of mammography. Moreover, the development of the necessary regulatory documents on the use of AI in medicine will begin, which will expand the capabilities of AI technologies in healthcare. The decree also outlines the creation of the first national repository for storing BD, including medical data, which gives some hope for the rapid development and introduction of AI technologies for healthcare in the Republic of Uzbekistan [35].

\section{Conclusions}

The success of $\mathrm{BD}$ in healthcare is recognized worldwide. However, different countries have unique approaches to the use of BD in practical healthcare. At the forefront of BD research are the United States, China, the EU, Japan, Singapore, and South Korea. There is also a surge in research and commercial interest in BD in developing countries. The use of a competent and strategic approach will allow these countries to avoid common mistakes and problems when creating and developing an ecosystem of BD and AI technologies.

Given that the Republic of Uzbekistan has made a strategic decision to transition the financial model of healthcare to social health insurance, BD will likely have an important role in calculating the cost of medical services, the volume of coverage for mandatory medical services, and will help to ensure equal and fair access to health services. BD are successfully used in business analytics, including in healthcare, which is of great benefit for countries not only with insured medicine, but in those with a healthcare model like Semashko or Beveridge.

To prepare for the introduction of BD and AI technologies to the healthcare system, we believe that it is imperative to pay great attention to cyber data security and other data privacy rules. We also believe it is increasingly important to ensure that the public is properly informed of the clinical opportunities that these new technologies present, to ensure an optimal balance between societal and individual benefits.

There are still some problems with the implementation of BD technologies in practical healthcare. One of the fundamental issues is the financial cost of developing, implementing and maintaining a system for collecting, storing and using BD, including the cost of highly qualified personnel, and expensive equipment and network infrastructure that needs to be regularly updated. Another problem is the confidentiality and security of data in healthcare. There have already been cases of leaks of electronic patient data, which present significant obstacles to the widespread use of BD in medicine. The volume of generated information in healthcare, which doubles every 2-3 months and continues to increase rapidly, also remains a significant obstacle. With the introduction of e-health in Uzbekistan, the flow of information about the healthcare system and personal medical data will be enormous. How we respond to the processing of such a flow of information and how we use this information will determine the expected improvement in the quality of medical care and, ultimately, an increase in the quality of life and its duration.

In conclusion, we would like to note the problem of storing information in electronic form. Ideally, it would be good to store information in at least 3-4 copies on hard drives or on cloud servers. However, this does not solve the general problem of the ever-increasing amount of medical information generated by patients and the healthcare system as a whole.

\section{References:}

1. Cambridge English Dictionary [Internet]. Cambridge: Cambridge University Press. Big Data [cited 2021 Feb 18]. Available from: https://dictionary.cambridge.org/dictionary/english/big-data

2. Collins English Dictionary [Internet]. Glasgow: HarperCollins Publishers. Big Data [cited 2021 Feb 18]. Available from: https://www.collinsdictionary.com/dictionary/english/big-data

3. Longman's Dictionary of Modern English [Internet]. London: Pearson. Big Data [cited 2021 Feb 18]. Available from: https://www.ldoceonline.com/dictionary/big-data

4. Lynch C. Big data: how do your data grow?. Nature. 2008; 455(7209): 28-29. https://doi.org/10.1038/455028a

5. Kornev M. [The history of the term "Big data". Dictionaries, academic and business periodicals]. RSUH/ 
RGGU Bulletin: Literary Theory. Linguistics. Cultural Studies, Series. 2018; 1: 81-85 (in Russian). https://doi. org/10.28995/2073-6355-2018-1-81-85

6. Kaplan A, Haenlein M. Siri, Siri, in my hand: who's the fairest in the land? On the interpretations, illustrations, and implications of artificial intelligence. Business Horizons. 2019; 62(1): 15-25. https://doi.org/10.1016/j. bushor.2018.08.004

7. Averkin AN, Gaase-Rapoport MG, Pospelov DA. [Explanatory dictionary of artificial intelligence]. Radio and Communication. 1992; 256 (in Russian).

8. McCarthy J. What is artificial intelligence? [Internet]. Stanford: Stanford University; 2007 [cited 2021 Apr 25]. Available from: http://www-formal.stanford.edu/jmc/whatisai/whatisai.html

9. Google Trends. Comparative analysis of the trend of search queries for the terms Big Data and Big Data in Health for the period 2009-2020 [Internet]. Mountain View: Google LLC [cited 2021 Feb 18]. Available from: https://trends.google.com/trends/explore?date $=2009-12-01 \% 202020-12-31 \& q=B i g \% 20$ Data,Big $\% 20$ Data\%20in\%20Health

10. Springer Link. Comparative analysis of the scientific queries in the Springer Nature for the terms Big Data and Big Data in Health for the period 2009-2020 [Internet]. Cham: Springer Nature Switzerland AG [cited 2021 Apr 24]. Available from: https://link.springer.com/search?query=Big+Data\&date-facet-mode=between\&facetstart-year $=2009$ \&previous-start-year $=2009 \&$ facet-end-year $=2020$ \&previous-end-year $=2020$

11. Laney D. 3D data management: controlling data volume, velocity and variety. META Group Research Note. Stanford: META Group; 2001.

12. www.developer.ibm.com [Internet]. North Castle: IBM. Big Data and analytics [cited 2021 Feb 19]. Available from: https://www.ibm.com/developerworks/ru/library/ba-adv-analytics-platform1

13. McNulty E. Understanding Big Data: the seven V's [Internet]. Berlin: Dataconomy; 2014 May 22 [cited 2021 Feb 19]. Available from: https://dataconomy.com/2014/05/seven-vs-big-data/

14. Biehn N. The missing V's in Big Data: viability and value [Internet]. San Francisco: WIRED [cited 2021 Feb 19]. Available from: https://www.wired.com/insights/2013/05/the-missing-vs-in-big-data-viability-and-value/

15. Stanford Medicine. Health trends report: harnessing the power of data in health. Stanford: Stanford University School of Medicine; 2017.

16. Densen P. Challenges and opportunities facing medical education. Transactions of the American Clinical and Climatological Association. 2011; 122: 48-58.

17. Morgan S. The 2020 data attack surface report [Internet]. Northport: Cybercrime Magazine; 2020 Jun 8 [cited 2021 Apr 26]. Available from: https://cybersecurityventures.com/the-world-will-store-200-zettabytes-ofdata-by-2025/

18. Faggella D. Where healthcare's Big Data actually comes from [Internet]. Boston: Emerj Artificial Intelligence Research; 2018 [cited 2021 Apr 26]. Available from: https://www.techemergence.com/where-healthcaresbig-data-actually-comes-from

19. Huesch D, Mosher TJ. Using it or losing it? The case for data scientists inside health care [Internet]. Waltham: NeJM Catalyst; 2017 May 4 [cited 2021 Apr 26]. Available from: https://catalyst.nejm.org/case-datascientists-inside-health-care/

20. Chen HZ, Bonneville R, Roychowdhury S. Implementing precision cancer medicine in the genomic era. Semin Cancer Biol. 2019; 55: 16-27. https://doi.org/10.1016/j.semcancer.2018.05.009

21. White S. A review of Big Data in health care: challenges and opportunities. Open Access Bioinformatics. 2014; 6: 13-18. https://doi.org/10.2147/OAB.S50519

22. Suter-Crazzolara C. Better patient outcomes through mining of biomedical Big Data. Frontiers in ICT. 2018; 5: 30. https://doi.org/10.3389/fict.2018.00030

23. Dash S, Shakyawar SK, Sharma M. Kaushik S. Big Data in healthcare: management, analysis and future prospects. Journal of Big Data. 2019; 6: 54. https://doi.org/10.1186/s40537-019-0217-0

24. Stieb DM, Boot CR, Turner MC. Promise and pitfalls in the application of Big Data to occupational and environmental health. BMC Public Health. 2017; 17: 372. https://doi.org/10.1186/s12889-017-4286-8

25. Collins B. Big Data and health economics: strengths, weaknesses, opportunities and threats. PharmacoEconomics. 2016; 34: 101-106. https://doi.org/10.1007/s40273-015-0306-7

26. Marshall DA, Burgos-Liz L, Pasupathy KS, Padula WV, IJzerman MJ, Wong KP, et al. Transforming healthcare delivery: integrating dynamic simulation modelling and Big Data in health economics and outcomes research. PharmacoEconomics. 2016; 34: 115-126. https://doi.org/10.1007/s40273-015-0330-7

27. Onukwugha E. Big Data and its role in health economics and outcomes research: a collection of perspectives on data sources, measurement, and analysis. PharmacoEconomics. 2016; 34: 91-93. https://doi.org/10.1007/ s40273-015-0378-4 
28. Johnson OA, Hall PS, Hulme C. NETIMIS: dynamic simulation of health economics outcomes using Big Data. PharmacoEconomics. 2016; 34: 107-114. https://doi.org/10.1007/s40273-016-0384-1

29. Fahr P, Buchanan J, Wordsworth S. A review of the challenges of using biomedical Big Data for economic evaluations of precision medicine. Appl Health Econ Health Policy. 2019; 17: 443-452. https://doi. org/10.1007/s40258-019-00474-7

30. Fiebig DG. Big Data: will it improve patient-centered care?.Patient. 2017; 10:133-139.https://doi.org/10.1007/ s40271-016-0201-0

31. Saracci R. Epidemiology in wonderland: Big Data and precision medicine. Eur J Epidemiol. 2018; 33: $245-257$. https://doi.org/10.1007/s10654-018-0385-9

32. Asche CV, Seal B, Kahler KH, Oehrlein EM, Baumgartner MG. Evaluation of healthcare interventions and Big Data: review of associated data issues. PharmacoEconomics. 2017; 35: 759-765. https://doi.org/10.1007/ s40273-017-0513-5

33. Peterson CB, Hamilton C, Hasvold P. From innovation to implementation: eHealth in the WHO European region. Copenhagen: WHO Regional Office for Europe; 2016. p. 98.

34. Kolasa K, Redekop KW, Berler A, Zah V, Asche CV. Future of data analytics in the era of the general data protection regulation in Europe. PharmacoEconomics. 2020; 38: 1021-1029. https://doi.org/10.1007/ s40273-020-00927-1

35. Resolution of the President of the Republic of Uzbekistan of $17^{\text {th }}$ Feb 2021 no. PP-4996. On measures to create conditions for the accelerated introduction of artificial intelligence technologies. National Database of Legislation. $18^{\text {th }}$ Feb 2021; no. 07/21/4996/0127. 